\title{
Antisickling and toxicological evaluation of the leaves of Scoparia dulcis Linn (Scrophulariaceae)
}

\author{
Tavs A. Abere ${ }^{1 *}$, Chiagozie J. Okoye ${ }^{1}$, Freddy O. Agoreyo ${ }^{2}$, Gerald I. Eze ${ }^{3}$, Rose I. Jesuorobo ${ }^{\text {, }}$ \\ Clement O. Egharevba ${ }^{1}$ and Pauline O. Aimator ${ }^{1}$
}

\begin{abstract}
Background: Scoparia dulcis Linn (Scrophulariaceae) together with other medicinal plants serve as antisickling remedies in Africa. This study was aimed at investigating the antisickling activity of the leaves of the plant as well as establishing the toxicological profile.

Method: Chemical tests were employed in phytochemical investigations. Evaluation of the antisickling activity involved the inhibition of sodium metabisulphite-induced sickling of the HbSS red blood cells obtained from confirmed sickle cell patients who were not in crises. Concentrations of the crude extract and its fractions were tested with normal saline and p-hydroxybenzoic acid serving as controls. Acute toxicological evaluation was carried out in mice while 30-day assessment was done in rats.

Results: Phytochemical screening revealed the presence of alkaloids, tannins, flavonoids and saponins. Percentage sickling inhibitions of the aqueous methanol extracts of $S$. dulcis were significant all through the period of assay $p<0.05$ compared to normal saline, but not significant with PHBA. The fractions had less activity compared to the crude extracts. The LD 50 of the extract in mice was above $8000 \mathrm{mg} / \mathrm{kg}$ body weight when administered orally. Toxicological evaluations at 250 and $500 \mathrm{mg} / \mathrm{kg}$ showed mild congestion in virtually all the target organs.

Conclusion: The antisickling results confirmed traditional usage of Scoparia dulcis in the management of Sickle cell disorders and a candidate for further investigations.
\end{abstract}

Keywords: Scoparia dulcis, Scrophulariaceae, Sickle cell disorders, Toxicological

\section{Background}

Scoparia dulcis Linn belongs to the Scrophulariaceae family. Common names include goatweed [1], scoparia weed, sweet broom in English, tape cava, tapixaba, vassourintia in Portuguese and escobillo in Spanish [2]. It is also known as roma fada in Hausa and aiya in Ibo [3]. It is native to the Neotropics, but it can be found throughout the tropical and subtropical world. Ethnomedicinally, S. dulcis is used to manage sickle cell disease in Nigeria [4], used for anaemia, burns, headache in Nicaragua [5], used to treat diabetes in India and hypertension in Taiwan [6] and also for bronchitis [7].

\footnotetext{
* Correspondence: eseabere@yahoo.com

'Department of Pharmacognosy, Faculty of Pharmacy, University of Benin, Benin City, Nigeria

Full list of author information is available at the end of the article
}

The diterpenoid Scoparinal, isolated from the plant demonstrated significant analgesic and anti-inflammatory activities $(P<0.001)$ in animals [8]. Scopadulcic acid B inhibited TPA-enhanced phospholipid synthesis in cultivated cells and inhibited the effect of TPA on skin tumor formulated in mice initiated with 7, 12 dimethylbenzyl anthracene [9]. The acetylated flavones glycosides of $S$. dulcis have NGR-potentiating activity which may be useful in treating neurological disorders [10]. High Performance Liquid Chromatography (HPLC) analysis of the aqueous fraction of $S$. dulcis revealed the presence of noradrenalins and adrenaline which had sympathomimetric effects [11].

Sickle Cell Disease (SCD) is one of the most prevalent morbidity and mortality diseases in Africa [12], but it also affects persons of Mediterranean, Caribbean, South and Central American, Arab and East Indian origins 
[13]. In Nigeria, the most common type of SCD is the homozygous (HbSS) form i.e. SCA. Estimates show that $25 \%$ of the Nigerian population are "carriers" of the Sickle cell trait i.e. HbAS [14]. SCD is a genetic blood disorder characterized by red blood cells (RBC) that assume an abnormal rigid sickled shape. The disease stems from inadequate oxygen transport by red blood cells. In vivo, sickled erythrocytes tend to block capillaries, causing stasis, and thereby starve organs of nutrients and oxygen, eventually causing hypofunction and complete tissue destruction [15]. Sickling decreases the RBC's flexibility and results in risk of various complications such as chronic renal failure [16], retinopathy [17], pulmonary hypertension [18], chronic pain [19], ischemia [20], stroke [21], priapsm and infraction of the penis [22].

Management of sickle cell is aimed at relieving pain, preventing infections and management of complications. First line clinical management of sickle cell anaemia includes use of hydroxyurea, folic acid, amino acids and blood transfusion to stabilize the patient's haemoglobin level [23]. These are quite expensive and have attendant risk factors, thereby gradually paving way for the consideration of condiments from natural sources as antisickling remedies [24]. The increasing interest in these condiments is not unconnected with the general innocuous nature of their sources, which most often are herbs and even at times food crops. Researches into antisickling properties of medicinal plants have been rewarding. This alternative therapy using phytomedicines has proven to not only reduce crises but also reverse sickling. Attempts to find alternative, cheaper, and less toxic therapies led to the scientific discovery of antisickling properties of some medicinal plants such as Cajanus cajan seeds, Zanthoxylum zanthoxyloides (Fagara) root, Carica papaya unripe fruit, and also Parquetina nigrescens whole plant extracts which boost blood volume - all these are locally used by traditional healers in Nigeria for diverse herbal remedies [23]. This study was designed to investigate the antisickling activity as well as the toxicological profile of Scoparia dulcis Linn (Euphorbiaceae), one of the recipes which have been used with acclaimed success by traditional healers in Nigeria in managing sickle cell anaemia.

\section{Methods}

\section{Collection of plant}

The leaves of Scoparia dulcis Linn (Euphorbiaceae) were collected in Benin City, Edo State, Nigeria. The plants were authenticated by the curator at the Herbarium of the Department of Pharmacognosy, Faculty of Pharmacy, University of Benin, Benin City where a voucher specimen was deposited.

\section{Animals}

Swiss albino mice (25. $92 \pm 1.05 \mathrm{~g})$ and Wistar rats (220. $00 \pm 16.44 \mathrm{~g}$ ) of both sexes were obtained from the Animal House, Department of Pharmacology and Toxicology, Faculty of Pharmacy, University of Benin, Benin City. All the animals were kept under standard environmental conditions and were handled according to international protocol for use of animals in experiments [25]. They were fed with standard pellets and tap water ad libitum. Ethical approval for the study was obtained from the College of Medicine, University of Benin Animal Ethics Committee (ADM/F. 22A/Vol. viii/349).

\section{Phytochemical investigation}

Chemical tests were employed in the preliminary phytochemical screening for various secondary metabolites such as tannins (phenazone; iron complex; formaldehyde and modified iron complex tests were carried out on the aqueous extract to detect the presence of hydrolysable, condensed and pseudo tannins); cardiac glycosides (Keller Killiani and Kedde tests were carried out on the methanolic extract to detect the presence of a deoxy sugar and to indicate the presence of a lactone ring on the cardenolides respectively); alkaloids (Mayer's, Dragendorff's, Wagner's and $1 \%$ picric acid reagents to detect the presence of alkaloidal salts and bases), saponins glycosides (frothing of the aqueous extract when shaken and haemolysis test on blood agar plates were carried out to indicate and confirm the presence of saponins); anthracene derivatives (Borntrager's test for combined and free anthraquinones, where aglycones were extracted using chloroform and shaken with dilute ammonia) and cyanogenetic glycosides (sodium picrate paper test were used to test for the presence of hydrocyanic acid in the sample. Conversion to sodium isopurpurate indicates the presence of cyanogenetic glycosides) [26, 27].

\section{Extraction and fractionation}

The fresh leaves of Scoparia dulcis Linn were airdried for $72 \mathrm{~h}$ and powdered using an electric mill. The powdered leaves $(4.2 \mathrm{~kg})$ were extracted with $\mathrm{MeOH}-\mathrm{H}_{2} \mathrm{O}$ (50: 50) $(5 \times 2 \mathrm{~L})$. Evaporating the solvent on a water bath yielded an extract $(0.78 \mathrm{~kg})$ which was subsequently re-suspended in water and successively partitioned into petroleum ether $(3 \times 2 \mathrm{~L})$, chloroform $(3 \times 2 \mathrm{~L})$ and $\mathrm{n}$-butanol $(3 \times 2 \mathrm{~L})$. The fractions were concentrated in vacuo at $40{ }^{\circ} \mathrm{C}$ and used for antisickling experiments.

\section{Antisickling screening HbSS blood samples}

HbSS Blood samples were collected by venipuncture from confirmed sickle cell patients not in crises on their clinic days at the Consultant Outpatient Department (COPD) of the University Teaching Hospital, Benin City, 
Nigeria. None of the patients used was recently transfused with HbAA blood.

\section{Antisickling activity evaluation}

The evaluation of the leaf extract and fractions of Scoparia dulcis Linn for antisickling activities was carried out using a modified method of Moody and co-workers [28]. Venipuncture blood samples from sickle cell anaemia patients not in crises were collected into EDTA bottles. Collected samples were centrifuged to remove the serum. The resulting packed erythrocytes were washed three times with sterile normal saline and centrifuged each time to remove the supernatant. $0.5 \mathrm{ml}$ of the washed erythrocytes were mixed each with $0.5 \mathrm{ml}$ of the different concentrations of the aqueous methanol extract $(100,300$ and $500 \mathrm{mg} / \mathrm{ml})$ or fractions $(500 \mathrm{mg} / \mathrm{ml})$ in uncovered test tubes. A $5 \mathrm{mg} / \mathrm{ml} \mathrm{solu-}$ tion of $\rho$-hydroxybenzoic acid (PHBA) in normal saline was used as the positive control while normal saline served as negative control. Samples were taken from the different mixtures and the remaining portions of the mixtures incubated for $3 \mathrm{~h}$, shaking occasionally.

A $2 \%$ Sodium metabisulphite $(0.5 \mathrm{ml})$ was added to each mixture to deoxygenate the system, mixed thoroughly and sealed with liquid paraffin. Samples were taken in five replicates from the different mixtures at $0 \mathrm{~min}$ and at subsequent $30 \mathrm{~min}$ interval until seven readings were obtained.

Each sample was smeared on a microscopic slide, fixed with $95 \%$ methanol, dried and stained with giemsa stain. Each slide was examined under the oil immersion light microscope and counting of 100 red cells in each sample. The numbers of both sickled and unsickled red blood cells were counted and the percentage of unsickled cells determined.

\section{Toxicological evaluation}

Swiss albino mice, divided into 6 groups of 5 animals per group were orally administered the extract at doses of 1000, 2000, 3000, 4000, 5000, 6000, 7000 and $8000 \mathrm{mg} / \mathrm{kg}$. The control group received only the vehicle (normal saline $5 \mathrm{ml} / \mathrm{kg}$ ). Each group of mice was placed in the test cage for a $30-\mathrm{min}$ habituation period before drug administration. The animals were observed for $10 \mathrm{~min}$ for the first $6 \mathrm{~h}$ and $10 \mathrm{~min}$ each day for the next two days. Lethality and gross toxicological features (convulsion, diarrhea, hyperactivity and pile-erection) were recorded for each group [29]. The animals were further observed for fourteen days.

Thirty Wistar rats were randomly distributed into three groups of ten rats each. The first (A) group served as control and received $5 \mathrm{ml} / \mathrm{kg}$ of normal saline (vehicle) while the second (B) and third (C) groups received oral doses of 250 and $500 \mathrm{mg} / \mathrm{kg}$ per day of the extract respectively for
30 consecutive days. The animals were observed for signs of toxicity (abnormal behaviours, writhing, convulsion, mood, motor activity and general body conditions) for 30 min each day. At the end of 30 days, the rats were sacrificed under chloroform anesthesia. Livers, lungs, hearts and testis were removed and preserved in $10 \%$ formaldehyde solution. Each organ was sectioned ( $6 \mu$ thick) embedded in paraffin wax and stained with hematoxylin and eosin [30].

\section{Statistical analysis}

Data are expressed as mean \pm SEM. The differences between the means were analyzed using one way analysis of variance (ANOVA). Values of $P<0.05$ were taken to imply statistical significance between compared data.

\section{Results}

Phytochemical screening

Phytochemical screening of the leaves of S. dulcis revealed the presence of tannins, flavonoids, saponins and alkaloids (Table 1).

\section{Sickling inhibitory activities of crude extracts and fractions of $S$. dulcis}

Percentage sickling inhibition of the various doses of $S$. dulcis extracts were significant all through the period of assay $(p<0.05)$ (Table 2$)$. There was no significant difference between the antisickling activity exhibited at 100 and $300 \mathrm{mg} / \mathrm{ml}$. The petroleum ether and n-butanol fractions were devoid of inhibitory activities.

\section{Toxicological evaluation}

The aqueous extract of $S$. dulcis did not produce any mortality up to the oral dose level of $8 \mathrm{~g} / \mathrm{kg}$ body weight in mice. There were no changes in behaviour, posture, nature and frequency of stooling, mood and motor activity. The animals did not convulse, exhibit writhing or die.

Daily administration of the extract for 30 days did not produce gross toxicological symptoms or deaths. Histopathology of the heart (Figs. 1 and 2) and liver (Figs. 3 and 4) showed mild vascular and portal congestions

Table 1 Phytochemical constituents of S. dulcis leaves

\begin{tabular}{lc}
\hline Classes of secondary metabolites & Inferences \\
\hline Alkaloids & + \\
Tannins & + \\
Flavonoids & - \\
Anthracene derivatives & + \\
Saponin glycosides & - \\
Cardiac glycosides & - \\
Cyanogenetic glycosides & \\
\hline Key: &
\end{tabular}


Table 2 The sickling inhibitory activities of Scoparia dulcis crude extracts and fractions

\begin{tabular}{|c|c|c|c|c|c|c|c|c|c|}
\hline \multirow[t]{2}{*}{ Time of incubation (min) } & \multicolumn{9}{|c|}{ Percentage inhibition (\%) } \\
\hline & $A^{*}$ & $B^{* *}$ & C & D & $E$ & $\mathrm{~F}$ & G & $\mathrm{H}$ & 1 \\
\hline 0 time before incubation & $59.2 \pm 0.12$ & $79.0 \pm 0.22$ & $59.8 \pm 1.04$ & $58.2 \pm 0.52$ & $60.0 \pm 1.34$ & $36.4 \pm 0.68$ & $58.0 \pm 0.81$ & $30.6 \pm 0.72$ & $57.0 \pm 0.50$ \\
\hline 30 & $50.2 \pm 0.31$ & $76.2 \pm 0.05$ & $48.0 \pm 0.08$ & $55.2 \pm 1.17$ & $60.0 \pm 0.66$ & $29.0 \pm 1.87$ & $58.2 \pm 0.86$ & $35.2 \pm 1.20$ & $58.0 \pm 1.92$ \\
\hline 60 & $49.0 \pm 0.64$ & $77.0 \pm 1.31$ & $54.2 \pm 0.12$ & $57.0 \pm 0.82$ & $66.2 \pm 1.24$ & $28.0 \pm 0.66$ & $59.0 \pm 1.34$ & $30.2 \pm 1.35$ & $56.0 \pm 0.04$ \\
\hline 90 & $43.4 \pm 0.27$ & $73.0 \pm 0.67$ & $49.4 \pm 1.65$ & $55.4 \pm 0.29$ & $69.0 \pm 0.95$ & $20.2 \pm 1.52$ & $60.6 \pm 1.10$ & $31.2 \pm 0.07$ & $50.4 \pm 1.66$ \\
\hline 120 & $43.2 \pm 0.32$ & $76.0 \pm 0.04$ & $59.0 \pm 1.04$ & $60.0 \pm 1.06$ & $75.2 \pm 0.73$ & $29.8 \pm 1.34$ & $58.0 \pm 0.26$ & $28.0 \pm 1.32$ & $45.4 \pm 0.47$ \\
\hline 150 & $40.4 \pm 0.41$ & $69.2 \pm 1.18$ & $50.6 \pm 0.06$ & $52.0 \pm 1.44$ & $55.0 \pm 1.42$ & $28.0 \pm 0.56$ & $48.0 \pm 1.05$ & $20.0 \pm 0.45$ & $43.0 \pm 1.40$ \\
\hline 180 & $39.0 \pm 0.52$ & $65.4 \pm 1.06$ & $50.0 \pm 0.82$ & $50.2 \pm 0.85$ & $52.4 \pm 0.54$ & $25.2 \pm 1.47$ & $45.0 \pm 1.12$ & $21.4 \pm 0.73$ & $43.0 \pm 1.33$ \\
\hline
\end{tabular}

Key:

$A=$ blood + Normal saline + Sodium metabisulphite

$\mathrm{B}=$ blood $+\mathrm{PHBA}+$ Sodium metabisulphite

$\mathrm{C}=$ blood + Crude extract of $S$. dulcis leaf at $100 \mathrm{mg} / \mathrm{ml}+$ Sodium metabisulphite

$\mathrm{D}=$ blood + Crude extract of $S$. dulcis leaf at $300 \mathrm{mg} / \mathrm{ml}+$ Sodium metabisulphite

$\mathrm{E}=$ blood + Crude extract of $\mathrm{S}$. dulcis leaf at $500 \mathrm{mg} / \mathrm{ml}+$ Sodium metabisulphite

$\mathrm{F}=$ blood + Petroleum ether fraction + Sodium metabisulphite

$\mathrm{G}=$ blood + Chloroform fraction + Sodium metabisulphite

$\mathrm{H}=$ blood $+\mathrm{N}$-butanol fraction + Sodium metabisulphite

I = blood + Aqueous fraction + Sodium metabisulphite

Percentage sickling inhibitions of the aqueous methanol extracts of $S$. dulcis were significant all through the period of assay $P<0$. 05 compared to normal saline*, but not with PHBA** $^{* *}$

respectively. There was no degeneration of tissues in the lungs (Figs. 5 and 6) and testis (Figs. 7 and 8) at both doses except for mild interstitial congestions.

\section{Discussion}

The Pharmacological activities of a given medicinal plant are associated with the type and nature of secondary plant metabolites present. Phytochemical evaluation of the leaves of $S$. dulcis revealed the presence of tannins, flavonoids, saponins and alkaloids. These compounds

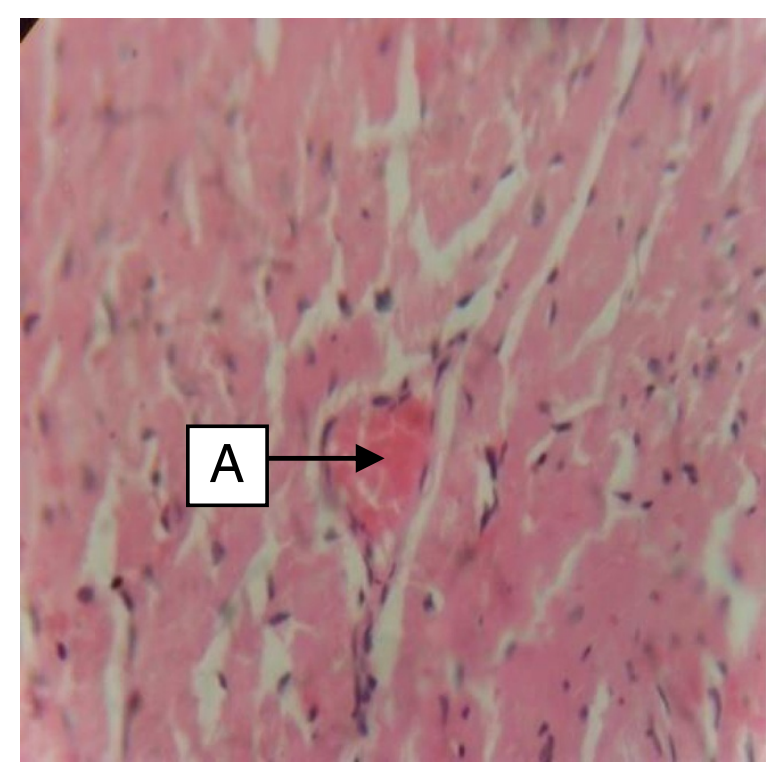

Fig. 1 Photomicrograph of the heart of rats administered with $250 \mathrm{mg} / \mathrm{kg}$ extract of $\mathrm{S}$. dulcis for 30 days showing mild vascular congestion A $(H \& E \times 400)$ detected in $S$. dulcis are known to possess medicinal properties and health promoting effects [31]. Previous investigations have attributed the antisickling activity of many medicinal plants used in the management of sickle cell diseases to their inherent phytochemicals. Saponins and flavonoids present in Hymenocardia acida leaves were responsible for its antisickling activity [32]. Similarly, anthraquinones, steroidal and cardiac glycosides present in Cissus populnea L. contributed to the antisickling properties of Ajawaron, an herbal product that is marketed in Nigeria [28].

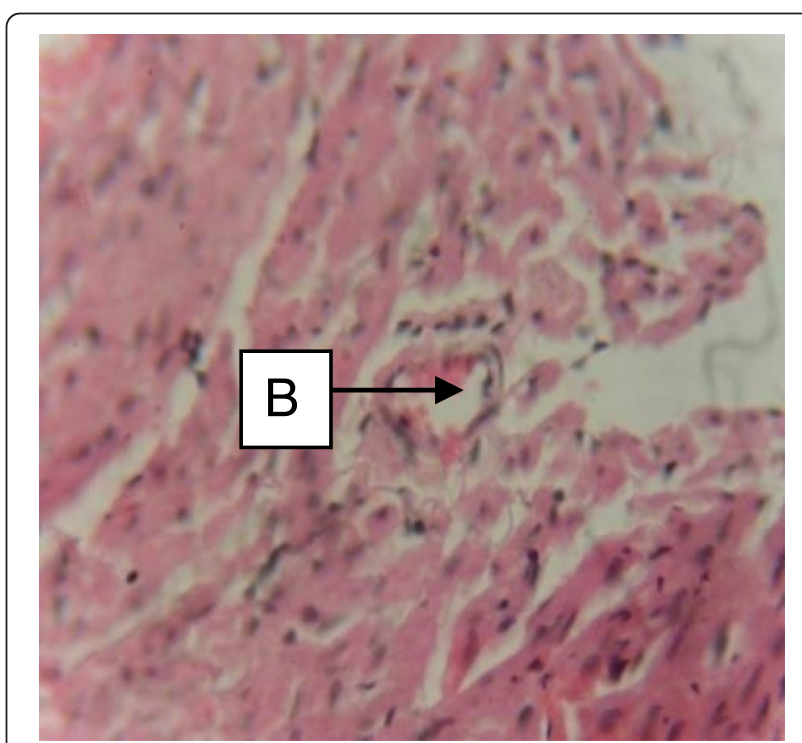

Fig. 2 Photomicrograph of the heart of rats administered with $500 \mathrm{mg} / \mathrm{kg}$ extract of $\mathrm{S}$. dulcis for 30 days showing mild vascular congestion B $(H \& E \times 400)$ 


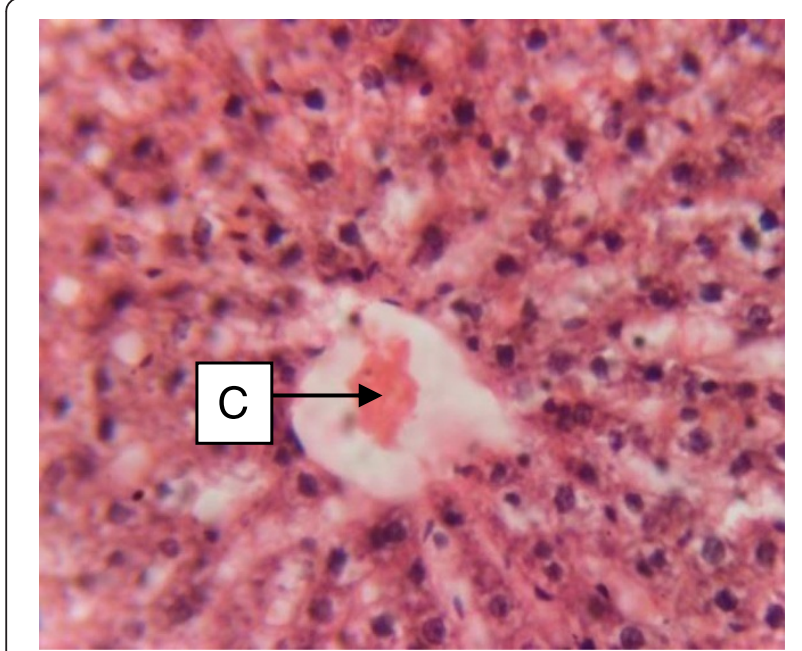

Fig. 3 Photomicrograph of the liver of rats administered with $250 \mathrm{mg} / \mathrm{kg}$ extract of $\mathrm{S}$. dulcis for 30 days showing mild vascular congestion $C(H \& E \times 400)$

The in-vitro techque adopted in the antisickling efficacy bioassay was based on the simulation of the major in-vivo sickling-precipitating factor (i.e. reduction of oxygen tension), using sodium metabisulphite as a physiologically acceptable reducing agent. Complete sickling of the sickle cell blood sample was brought about by the use of sodium metabisulpite solution $(2 \% \mathrm{w} / \mathrm{v})$ which helped to suck up oxygen from the red blood cell thus created a state of reduced oxygen tension which mimics the events that occurs during sickle cell crisis. This causes the cell to assume characteristic sickle cell shapes such as the crescent, holly leaf and spindle shapes. The use of erythrocyte suspension instead of

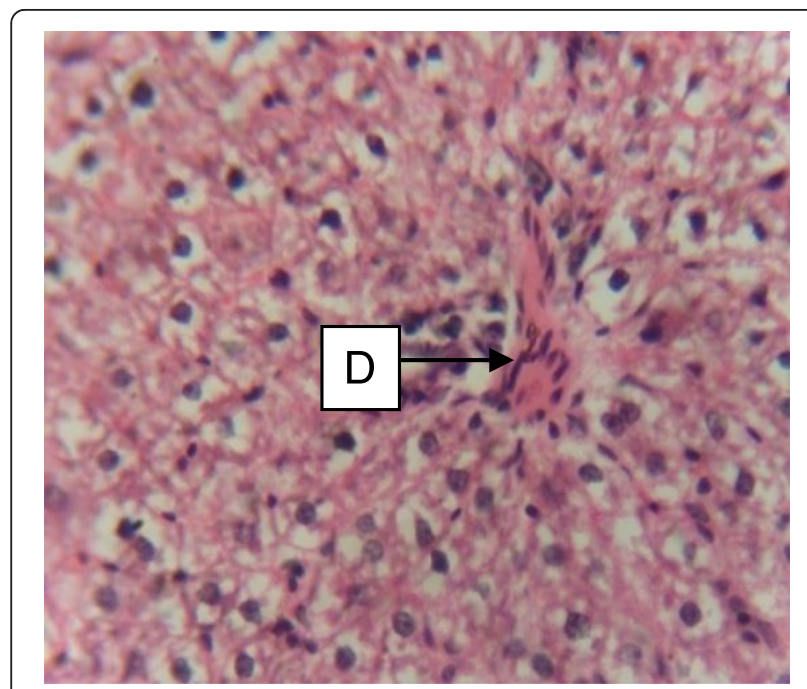

Fig. 4 Photomicrograph of the liver of rats administered with $500 \mathrm{mg} / \mathrm{kg}$ extract of $\mathrm{S}$. dulcis for 30 days showing mild portal congestion D $(H \& E \times 400)$

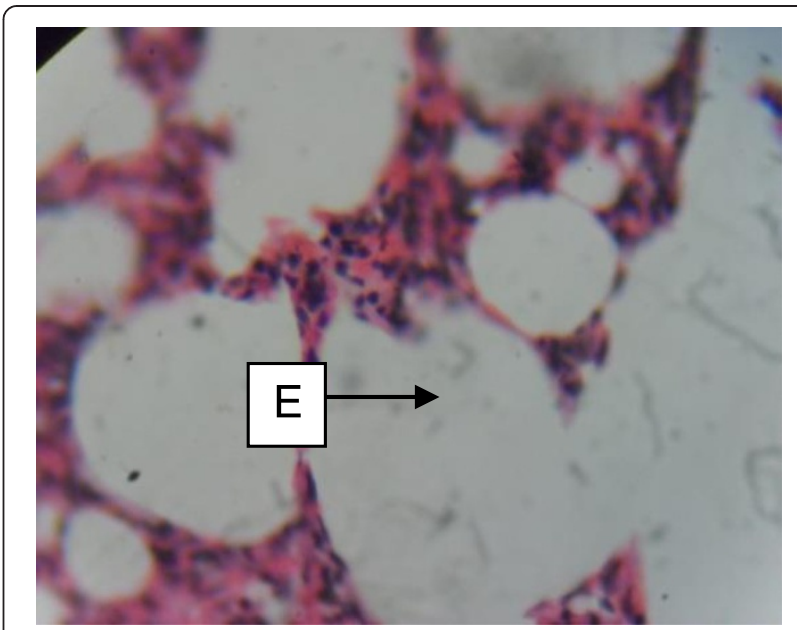

Fig. 5 Photomicrograph of the lung of rats administered with $250 \mathrm{mg} / \mathrm{kg}$ extract of $\mathrm{S}$. dulcis for 30 days showing unremarkable alveoli $E(H \& E \times 400)$

whole blood was particularly essential in ruling out the possibility of interactions of plasma component and products of their several immunological reactions and certain metabolic co-factors in general with the red blood cells [14]. Such interactions could significantly affect the shape and size of red blood cells and in the process inadvertently produce false negative or false positive results.

Aqueous and ethanol extracts of several phytomedicines have been evaluated for in vitro antisickling activity. Recent studies support some of the claims of traditional healers and suggest a possible correlation between the chemical composition of these plants and their uses in traditional medicine [33]. The aqueous

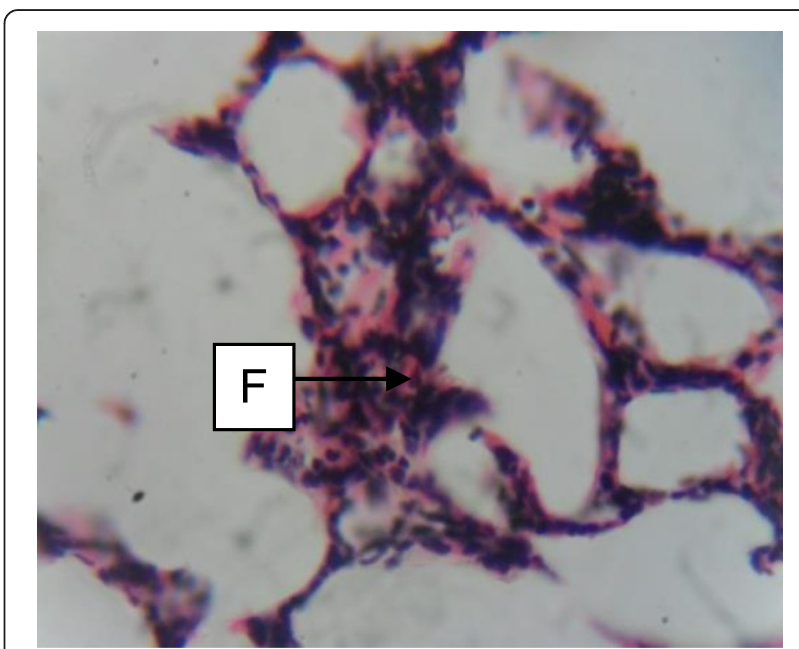

Fig. 6 Photomicrograph of the lung of rats administered with $500 \mathrm{mg} / \mathrm{kg}$ extract of $\mathrm{S}$. dulcis for 30 days showing mild interstitial congestion $F(H \& E \times 400)$ 


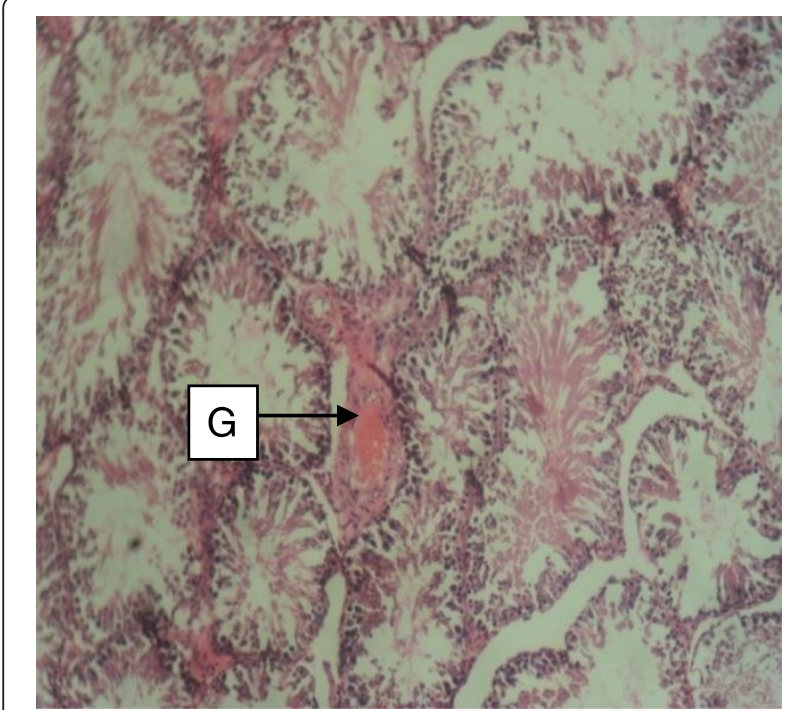

Fig. 7 Photomicrograph of the testis of rats administered with $250 \mathrm{mg} / \mathrm{kg}$ extract of $\mathrm{S}$. dulcis for 30 days showing moderate stroma congestion $\mathrm{G}(\mathrm{H} \& \mathrm{E} \times 400)$

methanol extracts of $S$. dulcis showed significant inhibitory effects at the concentrations (100, 300 and $500 \mathrm{mg} /$ $\mathrm{ml}$ ) on sodium metabisulphite-induced sickling. The chloroform and aqueous fractions of the crude extract also inhibited sodium metabisulphite induced sickling of the HbSS red blood cells to varying degrees. The inhibitory activity of $S$. dulcis could be due to the presence of bioactive compounds. The antisickling activity could be linked to the ability of the bioactive compounds present in $S$. dulcis to either inhibit in vitro polymerization of

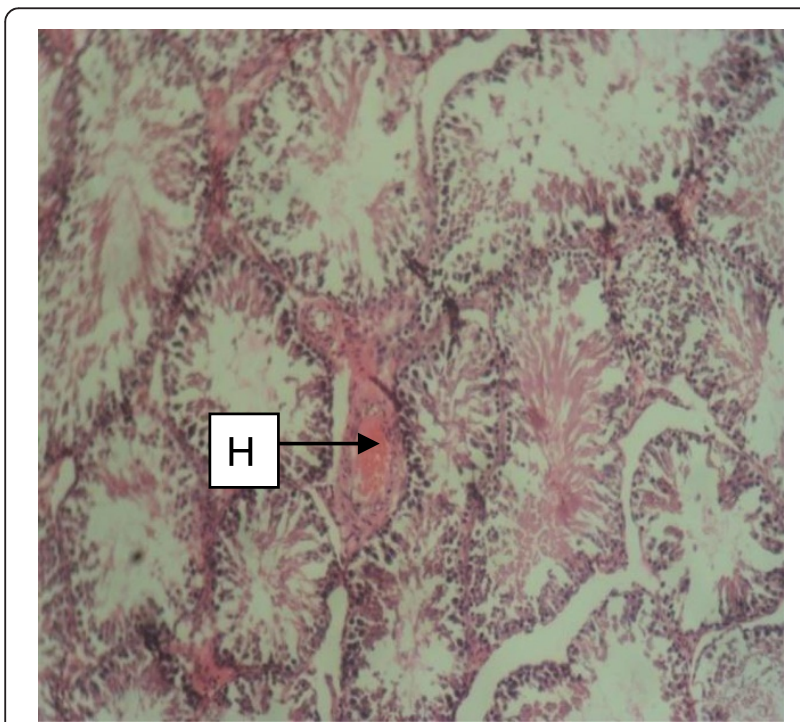

Fig. 8 Photomicrograph of the testis of rats administered with $500 \mathrm{mg} / \mathrm{kg}$ extract of S. dulcis for 30 days showing moderate stroma congestion $\mathrm{H}(\mathrm{H} \& \mathrm{E} \times 400)$ haemoglobin or to some structural modification linked to the environment of haemoglobin by the extracts and fractions [34].

Toxicological studies for all herbal medicines including the determination of their median lethal dose (LD 50) and other such parameters essential for a proper dosage are desirable and necessary. If there is the suspected need for more detailed studies, such herbal medicines may be subjected to sub-acute tests. The general purpose of the sub-acute toxicity tests is to determine the organs that are likely to be susceptible to toxicity by the herbal medicines. Histopathological effects of the administration of 250 and $500 \mathrm{mg} / \mathrm{kg}$ per day of the extract of $S$. dulcis to rats showed no evidence of tissue necrosis on the heart, liver, lung and testis. There were no marked adverse alterations or degeneration of tissues since these vital organs showed normal architectures suggesting no morphological disruptions as compared with the control group. It is an indication of the low toxicity of the extract [29], therefore S. dulcis could be said to be relatively safe.

\section{Conclusion}

On the basis of the results obtained from the pharmacological investigations, it could be said that Scoparia dulcis possesses antisickling properties, indicating that it has a role in the treatment of sickle cell disorders and a good candidate for further investigations.

\section{Ethical approval}

Ethical approval for the study was obtained from the College of Medicine, University of Benin Animal Ethics Committee (ADM/F. 22A/Vol. viii/349).

Approval was also obtained from the Sickle Cell Centre, Benin City, Nigeria through the Edo State Health Management Board for the use of consenting sickle cell patients for the study.

\section{Competing interests}

No conflict of interest associated with this work.

\section{Authors' contributions}

We declare that this work was done by the authors named in this article and all liabilities pertaining to claims relating to the content of this article will be borne by the authors. TAA conceived and designed the study. CJO, RIJ, COE and POA collected and analysed antisickling data. FOA and GIE carried out toxicological works. All authors read and approved the final manuscript.

\section{Acknowledgement}

We acknowledge the contributions of Mrs. Comfort Braimah and Mrs. Florence Adesina, Chief Laboratory Technologists of Anatomy and Pharmacognosy, respectively of the University of Benin, Benin City for their technical input.

\section{Source of funding}

There was no funding from any source; rather, the study was wholly funded from personal money of the researchers. 


\section{Author details}

'Department of Pharmacognosy, Faculty of Pharmacy, University of Benin, Benin City, Nigeria. ${ }^{2}$ Department of Physiology, College of Medical Sciences, University of Benin, Benin City, Nigeria. ${ }^{3}$ Department of Anatomy, College of Medical Sciences, University of Benin, Benin City, Nigeria.

Received: 2 February 2015 Accepted: 2 November 2015

Published online: 23 November 2015

\section{References}

1. Jain R, Singh M. Factors affecting Goatweed (Scoparia dulcis) seed germination. Weed Sci. 1989;37(6):766-70.

2. Scoparia dulcis. Germplasm Resources Information Network.

3. Orhue NEJ, Nwanze EAC. Anti-anaemic properties of Scoparia dulcis in Trypanosoma brucci infected rabbits. Afr J Biochem Res. 2009;3(5):245-9.

4. Murti $K$, Panchal M, Poonam T, Singh R. Pharmacological properties of Scoparia dulcis. Rev Pharmacol. 2012;3(8):344.

5. Rashid MH, Khalekuzzaman MJ, Hasan MF, Das R, Hussain MS, Mahabbat S. Establishment of an efficient method for micropropagation of an important medicinal herb from short tips and nodal segments. Int J Sustainable Crop Prod. 2009:4(1):5-9.

6. Pari L, Latha M, Rao CA. Effect of Scoparia dulcis extract on insulin receptors in Streptozotocin induced diabetic rat: studies on insulin binding to erythrocytes. J Basic Clin Physiol Pharmacol. 2004;15:233-40.

7. Freire SM, Torres LM, Souccar C, Lapa AJ. Sympathomimetic effects of Scoparia isolated from plant extract. J Pharm Pharmacol. 1996;48(6):624-8.

8. Freire SM, Torres LM, Rogue NF, Souccar C, Lapa AJ. Analgesic activity of a triterpenes isolated from Scoparia dulcis Linn (Vassourinha). Mem Inst Oswaldo Cruz. 1991;86:149-51.

9. Nishino $H$, Hayashi T, Arisawa M, Satom Y, Iwashima A. Antitumor promoting activity of Scopadulcic acid B, isolated from the medicinal plant Scoparia dulcis L. Oncology. 1993:50:100-3.

10. Li Y, Ohizumi Y. Search for constituents with neurotrophia factorpotentiating activity from the medicinal plants of Paraguay and Thailand. J Pharm Soc Jpn. 2004;124:417-24.

11. De Farias Freire SM, Torres LM, Souccar C. Mimetic effects of Scoparia dulcis L. and Catecholamines isolated from plant extracts. J Pharmacol Pharmacother. 1996:48:624-8

12. Serjent GR. Sickle cell disease. 3rd ed. New York: Oxford University Press; 2001. p. 429-35.

13. Steinberg MH. Sickle cell disease. Hematology. 2004;1:35.

14. Coker HAB, Kehinde MO, Temiye EO, Banjo AAF, Elesha SO, Sofola OA, Ajala OS, Alaribe SC, Adesegun SA, Owolabi MO, Sodipo JOA, Renner JK. Does re-hydration necessarily imply re-oxygenation in sickling reversal. The Gardos phenomenon-revisited. A case for Cellod-S herbal remedy. J Pharm Sci Pharm Pract. 2006:8:122-31.

15. Bunn HF. Pathogenesis and treatment of sickle cell diseases. N Engl J Med. 1997;337(1):762-9

16. Powars DR, Elliott-Mills DD, Chan L, Niland J, Hiti AL, Opas LM, Johnson C. Chronic renal failure in sickle cell disease: risk factors, clinical course and mortality. Ann Intern Med. 1991;115(8):614-20.

17. Elagouz M, Jyothi S, Gupta B, Sivaprasad S. Sickle cell disease and the eye: old and new concepts. Surv Ophthalmol. 2010;55(4):359-77.

18. Gladwin MT, Sacddev V, Jison ML, Shizukuda Y, Plehn JF, Minter K, Brown B, Coles WA, Nichols JS, Ernst I, Hunter LA, Blackwelder WC, Schechter AN, Rodgers GP, Castro O, Oqnibere FP. Pulmonary hypertension as a risk factor for death in patients with sickle cel disease. N Engl J Med. 2004;350(9):886-95.

19. Smith WR, Penberthy LT, Bovbjerg VE, McClish DK, Roberts JD, Dahman B, Aisiku IP, Levenson JL, Roseff SD. Daily assessment of pain in adults with sickle cell disease. Ann Intern Med. 2008;148(2):94-101.

20. Marti-Carvajal A, Dunlop B, Agreda-perez L. Treatment for avascular necrosis of bone in people with sickle cell disease. J Clin Pathol. 2004;33(7):622-5.

21. Adams RJ, Ohene-Frempong K, Wang W. Sickle cell and the brain. Hematology. 2001;1:31-46.

22. Chrouser KL, Ajiboye OB, Oyetunji TA, Chang DC. Priapism in the United States: the changing role of sickle cell disease. Am J Surg. 2011;101(4):468-74.

23. Imaga NA. Phytomedicines and Nutraceuticals: Alternative therapeutics for sickle cell anaemia. Sci World J. 2013;2013:269659.
24. Abere TA, Egharevba CO, Chukwurah IO. Pharmacognostic evaluation and antisickling activity of the leaves of Securinega virosa Roxb. ex Willd (Euphorbiaceae). Afr J Biotechnol. 2014;13(40):4040-5.

25. National Institute of Health. Public health service policy on humane care and use of laboratory animals. USA: Office of the laboratory animal welfare 2002. p. 1-19.

26. Evans WC. Trease and Evans Pharmacognosy. 15th ed. Toronto: WB Saunders; 2006. p. 512

27. Harborne JB. Phytochemical methods. A guide to modern technique of plant analysis. 1st ed. London: Chapman and Hill; 1992. p. 279.

28. Moody JO, Ojo OO, Omotade OO, Adeyemi AA, Olumese PE, Ogundipe OO. Anti-sickling potential of a Nigerian herbal formula (ajawaron HF) and the major plant component (Cissus populaea L. CPK). Phytochemical Res. 2003;17(10):1173-6.

29. Dietrich L. Anew approach to practical acute toxicity testing. Achives Toxicol. 1983;54:275-87.

30. Adefemi OA, Elujoba AA, Odesanmi WO. Evaluation of the toxicity potential of Cassia podocarpa with reference to official Senna. West Afr J Pharmacol Drug Res. 1988:8:41-8.

31. Uzama D, Bwai MD, Orijajogun OY, Olajide O, Sunday AT. The antioxidant potentials and phytochemical properties of the Hexane, Ethyl acetate and Ethanolic extracts of Securinega virosa (Euphorbiaceae) leaves. J Appl Pharm Sci. 2013;3(05):131-5.

32. Ibrahim H, Sani FS, Danladi BH, Ahmadu AA. Phytochemical and antisickling studies of the leaves of Hymenocardia acida Tul (Euphorbiaceae). Pak J Biol Sci. 2007:10(5):788-91.

33. Mpiana PT, Ishibangu DST, Shetonde OM, Ngbolua KN. In vitro antidrepanocytary activity (anti-sickle cell anaemia) of some Congolese plants. Phytomedicine. 2007;14(2-3):192-5.

34. Nanfack P, Biapa NPC, Pieme CA, Ama MVJ, Moukette B, Ngogang YJ. The in vitro antisickling and antioxidant effects of aqueous extracts of Zanthoxyllum heitzii on sickle cell disorder. BMC Complement Altern Med. 2013;13:162.

\section{Submit your next manuscript to BioMed Central and take full advantage of:}

- Convenient online submission

- Thorough peer review

- No space constraints or color figure charges

- Immediate publication on acceptance

- Inclusion in PubMed, CAS, Scopus and Google Scholar

- Research which is freely available for redistribution 